\title{
森林における光合成・呼吸活動に伴う貯熱量
}

\author{
斎藤 琢 $*$ ・玉川一郎 $*$ ・村岡裕由 $*$ ・ 小泉 博 $* *$ \\ $\left(\begin{array}{c}* \text { 岐阜大学・流域圈科学研究センター } \\ * * \text { 早稲田大学・教育学部生物学専修 }\end{array}\right)$
}

\section{Heat storage due to photosynthesis and respiration activities in forests}

Taku M. SaItoH*, Ichiro TAmagawa*, Hiroyuki MuraOKA*, and Hiroshi Kolzumi**

$\left(\begin{array}{c}* \text { River Basin Research Center, Gifu University, 1-1 Yanagido, Gifu 501-1193, Japan } \\ * * \text { Department of Biology, Faculty of Education, Waseda University, } \\ \text { 2-2 Wakamatsucho, Shinjuku, Tokyo 162-8480, Japan }\end{array}\right)$

\begin{abstract}
This study evaluated heat storage flux or released flux due to biotic activity $\left(S_{\mathrm{C}}\right)$ in forests. First, as a case study, we investigated diurnal pattern of $S_{\mathrm{C}}$ over an evergreen coniferous forest via a three-year continuous eddy-covariance $\mathrm{CO}_{2}$ flux measurement. We clarified that (1) in some case, $S_{\mathrm{C}}$ reached over $15 \%$ of total heat storage flux during the snow-free period (May-October), (2) $S_{\mathrm{C}}$ was $4.3 \mathrm{~W} \mathrm{~m}^{-2}$ on average and reached $4.9-7.0 \%$ of average sensible and latent heat fluxes during the snow-free period. Second, we estimated $S_{\mathrm{C}}$ by using net ecosystem exchange over several forest ecosystems as reported by previous studies. During the snow-free period over several forest ecosystems, the maximum $S \mathrm{c}$ and daily amplitude exceed 3-12 and 4-17 $\mathrm{W} \mathrm{m}^{-2}$ respectively. Those values were comparable to those of the latent heat storage flux in the air layer from the ground surface to the level of eddy-covariance measurement over several forest ecosystems as shown by previous reports. Our findings suggest that $S_{\mathrm{C}}$ cannot be always ignored. We would need to examine whether $S_{\mathrm{C}}$ can be ignored based on the circumstances of the targeted research.
\end{abstract}

Key words: Eddy-covariance, Forest, Heat storage, Photosynthesis, Respiration.

キーワード：渦相関法，光合成，呼吸，森林，貯熱量

\section{1.はじめに}

森林に打ける熱収支は，地表面の水循環・物質循環 に影響を及ぼすだけでなく, 地球規模の熱・水・物質 輸送に影響を及ぼすため，森林における熱収支の実測 に基づく研究 (例えば, Foken, 2008) および熱収支の モデル化の研究 (例えば, Bonan et al., 1997; Sellers et al., 1996) が数多く行われている。森林表面におけ る鉛直一次元の熱収支は以下の式で表される (例えば, Bernhofer et al., 2003)。

$$
R_{\mathrm{n}}-G-S=H+L E
$$

ここで $R_{\mathrm{n}}$ は森林への入力を正とする純放射量 $\left(\mathrm{W} \mathrm{m}^{-2}\right)$, $G$ は地中への熱流量 $\left(\mathrm{W} \mathrm{m}^{-2}\right), S$ は乱流フラックス観測高

20010 年 7 月 26 日 受付, 2010 年 9 月 15 日 受理
度と地表面の間の大気，植生による貯熱量変化および生 物活動による貯熱量変化 $\left(\mathrm{W} \mathrm{m}^{-2}\right), H$ は大気への顕熱つ ラックス $\left(\mathrm{W} \mathrm{m}^{-2}\right), L E$ は大気への潜熱フラックス $\left(\mathrm{W} \mathrm{m}^{-2}\right)$ である。なお, 積雪がある場合は, 積雪の融解熱の項が 考慮される。これまでの研究から, 30 分程度の短い時間 スケールでは, $S$ の最大值は $60 \mathrm{~W} \mathrm{~m}^{-2}$ 程度に達するこ とが報告されており， $S$ が $R_{\mathrm{n}}$ の $10 \%$ 以上に達する場合も ある(例えば Oliphant et al., 2004)。このため, 各項を 独立に計測した研究では， $S$ を無視することによって左辺 が過大評価されることが報告されており，森林の熱収支に おける $S$ の重要性が指摘されてきた (例えば, Moderow et al., 2009)。S は貯熱の過程によって以下のように区分 することができる。

$$
S=S_{\mathrm{H}}+S_{\mathrm{LE}}+S_{\mathrm{V}}+S_{\mathrm{C}}
$$


ここで $S_{\mathrm{H}}$ は乱流フラックス観測高度と地表面の間の顕熱 に関連した貯熱量変化 $\left(\mathrm{W} \mathrm{m}^{-2}\right), S_{\mathrm{LE}}$ は乱流フラックス 観測高度と地表面の間の水蒸気量の変化に伴って生じる 潜熱に関連した貯熱量変化 $\left(\mathrm{W} \mathrm{m}^{-2}\right), S_{\mathrm{V}}$ は植物体の貯 熱量変化 $\left(\mathrm{W} \mathrm{m}{ }^{-2}\right), S_{\mathrm{C}}$ は植物体の光合成・呼吸活動に 伴う貯熱・放熱量変化 $\left(\mathrm{W} \mathrm{m}^{-2}\right)$ である。これまで, $S_{\mathrm{H}}$,

$S_{\mathrm{LE}}, S_{\mathrm{V}}$ 各項の評価や $S$ に関する議論は多くの研究で行 われてきたが, 光合成および呼吸に関連した貯熱・放熱 量についてはほとんどの研究で無視されており (例えば,

McCaughey, 1985; McCaughey and Saxton, 1988; Jaeger and Kessler, 1996; Vogt et al., 1996; Wilson and Baldocchi, 2000; Oliphant et al., 2004), ごく少 数の文献 ( 例えば, Blanken et al., 1997; Bernhofer et al., 2003; Moderow et al., 2009) で議論されているだけ である。このため, $S_{\mathrm{C}}$ を構成する光合成に伴う貯熱量や 呼吸活動に伴う放熱量に関する詳細については, ほとん ど分かっていない。そこで, 本研究では, 森林における 光合成に伴う貯熱および呼吸に伴う放熱に焦点を当て研 究を行う。光合成に伴う貯熱量および呼吸に伴う放熱量 の正味の貯熱量変化 $S_{\mathrm{NEP}}\left(\right.$ すなわち $S_{\mathrm{C}}$ ) は次式で表される。

$$
S_{\mathrm{C}}=S_{\mathrm{NEP}}=S_{\mathrm{GPP}}+S_{\mathrm{RE}}
$$

ここで, $S_{\mathrm{GPP}}$ は光合成に伴う貯熱量変化 $\left(\mathrm{W} \mathrm{m}^{-2}\right), S_{\mathrm{RE}}$ は呼吸に伴う貯熱量変化 $\left(\mathrm{W} \mathrm{m}^{-2}\right)$ であり, 正の值が貯熱, 負の值が放熱である。なお, 光合成に伴う熱輸送は貯熱 過程のため $S_{\mathrm{GPP}}$ は常にゼロ以上の值となり, 呼吸による 熱輸送は放熱過程のため $S_{\mathrm{RE}}$ は常に負の值となる。 $S_{\mathrm{RE}}$ は地上部の植物体による呼吸に伴う貯熱量変化 $\left(S_{\text {Rabove }}\right.$; $\left.\mathrm{W} \mathrm{m}^{-2}\right)$ と地下部の土㙵呼吸に伴う貯熱量変化 $\left(S_{\text {Rsoil }} ; \mathrm{W}\right.$ $\mathrm{m}^{-2}$ )に分離可能であり以下の式で表される。

$$
S_{\mathrm{RE}}=S_{\text {Rabove }}+S_{\text {Rsoil }}
$$

本研究では, まず, 事例研究として, 日本の代表的な 植生であるスギ・ヒノキが優占する常緑針葉樹林を対象 として渦相関法によって推定された 3 年間に渡る長期連 続 $\mathrm{CO}_{2}$ フラックスを基に, (3) 式, (4) 式の各項で表さ れる光合成, 呼吸に伴う貯熱量, 放熱量の詳細を定量 的に明らかにする。さらに, 過去の炭素交換量研究で得 られた様々な森林における純生態系交換量 (NEE: Net ecosystem exchange) の值を基に $S_{\mathrm{NEP}}$ を推定し, 森林 における $S_{\mathrm{NEP}}$ の代表的な值を明らかにし, 熱収支の各項 と比較することで光合成, 呼吸に伴う貯熱量, 放熱量の 重要性について検討する。

\section{2. 方 法}

\section{1 観測サイト}

事例研究の対象とした観測サイトは岐阜県高山市から 約 $13 \mathrm{~km}$ 東に位置するAsiaFlux TKCサイト $\left(36^{\circ} 08^{\prime} \mathrm{N}\right.$, $137^{\circ} 22^{\prime} \mathrm{E} ; 800 \mathrm{~m}$ a.s.1.) である。本地域は冷温带に属し, 冬季 (11月〜 4月)には降雪がある。高山市内のアメダ 又観測地点 (560 m a.s.1.) の過去 20 年の平均気温打よ び年降水量は $11.2^{\circ} \mathrm{C}$ おび $1723 \mathrm{~mm}$ であり, ともに明 瞭な季節変化を示す。観測は TKC サイトの中心に位置 する約 $30 \mathrm{~m}$ のタワーとその周辺の 0.15 ha の生態系プ ロットで行われた。TKCサイトでは, 2005 年 3 月より微 気象計測を, 2005 年 9 月より渦相関法によるタワーフラッ クス計測を連続的に行っている。本研究では, 2005 年 11 月〜 2008 年 10 月の期間のデータを用いて解析を行つ た。サイトの周辺 $2 \mathrm{~km} \times 2 \mathrm{~km}$ は $40 \sim 50$ 年生のスギ. ヒノキが優占する常緑針葉樹林である。ただし, タワー北 側方向には, 落葉広葉樹林, 農地, 家屋などが点在して おり, 常緑針葉樹林のフェッチは, $100 \sim 1000 \mathrm{~m}$ であ る。本研究では十分なフェッチが得られない渦相関法に よるフラックスデータは除外し解析を行った。詳細につい ては Saitoh et al. (2010)を参照されたい。TKCサイト の植物体面積指数の年平均值は $4.9 \sim 5.2 \mathrm{~m}^{2} \mathrm{~m}^{-2}$ であり, 季節変化は小さい。タワー周辺の樹高は約 $20 \mathrm{~m}$, 樹 冠はほとんど閉じており, 密な森林といえる (Lee et al., 2008)。

\section{2 観測方法}

\subsection{1 微気象観測}

高度 $30 \mathrm{~m}$ の観測タワー頂上において光量子センサー (LI-190SZ, Li-Cor, Lincoln, NE) によって光合成有効 放射量 $\left(Q_{\mathrm{d}}\right)$ を計測した。また, 観測タワー 8 高度 $(30.2$, $22.8,18.4,14.7,10.6,6.5,3.6,1.3 \mathrm{~m})$ で温湿度プロー ブ(HMP45A, Vaisala, Vantaa, Finland)を用いて温度・ 湿度を計測した。土壌中の深度 $0.05 \mathrm{~m}$ では, 温度プロー ブ (Model 107, Campbell Scientific, Logann, UT) に よって地温を計測し, 土壌呼吸量推定に利用した。これ らのデータは 5 秒間隔で取得し 1 分おきに CR $23 X$ デー タロガー (Campbell Scientific) に蓄積した。本研究では, 30 分平均值として整理したデータを $N E E$, 総一次生産 量 (GPP: Gross primary production) 拉よび生態系呼 吸量 (RE: Ecosystem respiration) の推定の際に利用し た。

\subsection{2 タワーフラックス観測}

$S_{\mathrm{NEP}}, S_{\mathrm{GPP}}, S_{\mathrm{RE}}$ の推定のために渦相関法による $\mathrm{CO}_{2}$ フラックス計測を行い, $N E E, G P P, R E$ の值を得た。 $N E E$ は, 樹冠上 $\mathrm{CO}_{2}$ フラックスと貯留 $\mathrm{CO}_{2}$ フラックス 
の和によって算出された。ここで，樹冠上 $\mathrm{CO}_{2}$ フラックス とは, 渦相関法によって得られたフラックス值であり, 貯 留 $\mathrm{CO}_{2}$ フラックスとは渦相関法フラックス計測高度と地表 面の間の $\mathrm{CO}_{2}$ 濃度の時間変化によって得られるフラック ス值である。高度 $30 \mathrm{~m}$ の観測タワー頂上 ( 樹冠上約 10 m) に設置された 3 次元超音波風速温度計 (R3-50, Gill Instruments, Hampshire, UK) とオープンパス式赤外線 $\mathrm{CO}_{2} / \mathrm{H}_{2} \mathrm{O}$ 分析計 (LI-7500, Li-Cor, Lincoln, NE) によ り樹冠上フラックス計測をサンプリング周波数 $10 \mathrm{~Hz}$ で行 い, 30 分間隔の樹冠上 $\mathrm{CO}_{2}$ フラックスを算出した。そ の際, $H$ および $L E$ も算出した。貯留 $\mathrm{CO}_{2}$ フラックスを 得るため, 観測タワーにおいて渦相関法計測高度以下の $\mathrm{CO}_{2}$ 濃度鉛直プロファイル計測を行った。ダイヤフラムポ ンプ, 電磁弁, 除湿器, 流量安定装置, プログラマブルデー タロガーからなる自動大気サンプリング装置により 8 高度 (30.2, 22.8, 18.4, 14.7, 10.6, 6.5, 3.6, 1.3 m) からサン プル空気を取得し, クローズドパス式赤外線 $\mathrm{CO}_{2}$ 分析計 (Li-Cor, LI-820) により 30 分間隔で $\mathrm{CO}_{2}$ 濃度の分析を 行った。これら 8 高度の $\mathrm{CO}_{2}$ 濃度データと同高度の気温 データにより 30 分毎の貯留 $\mathrm{CO}_{2}$ フラックスを算出した。

樹冠上 $\mathrm{CO}_{2}$ フラックスと貯留 $\mathrm{CO}_{2}$ フラックスの和に よって得られた $N E E$ データを基に $N E E, G P P, R E$ の 欠測值補完を行い, 2005 年 11 月から 2008 年 10 月の $N E E, G P P, R E$ の久測值補完済みデータセットを作成 し本研究の解析に用いた。欠測值補完には, 一般的に用 いられる年間を通した夜間 $N E E$ に対する温度依存性曲線 と月毎の光 - 光合成曲線を用いた。夜間 $N E E$ に関して は, 摩擦速度が $0.35 \mathrm{~m} \mathrm{~s}^{-1}$ 以上のデータを採用し (Saitoh et al., 2010), 幅広い温度幅に対応可能な以下の Lloyd and Taylor (1994) 式を用いて REの欠測值補完を行った。

$$
R E=R_{\text {ref }} \exp \left\{E_{0}\left(\frac{1}{56.02}-\frac{1}{T-227.13}\right)\right\}
$$

ここで $R_{\mathrm{ref}}$ は参照温度 $(283.15 \mathrm{~K})$ における $R E, E_{0}$ は 気体定数と活性化エネルギーの比 $(\mathrm{K}), T$ は渦相関法計 測高度における気温 $(\mathrm{K})$ である。本研究では, 各年の 1 月から 12 月のデータを用いて (5) 式のパラメータを定義 した。なお，2005 年 11 月〜 12 月の久測值補完につい ては, 2005 年 9 月から 2006 年 8 月のデータを用いて パラメータを定義した。GPPの欠測值補完を行うために, $R E$ と $N E E$ の差から得られる 30 分毎の $G P P$ と $Q_{\mathrm{d}}$ の值 を利用し，次式に示す Michaelis-Menten 曲線 (例えば, Aubinet et al., 2001)を用いて各月のパラメータを定義 した。

$$
F_{\mathrm{GPP}}=\frac{A_{\text {max }} Q_{\mathrm{d}}}{Q_{\mathrm{d}}+A_{\max } / a_{\mathrm{s}}}
$$

ここで, $A_{\max }$ は群落スケールの最大光合成速度 $(\mu \mathrm{mol}$ $\left.\mathrm{m}^{-2} \mathrm{~s}^{-1}\right) ， a_{\mathrm{s}}$ は曲線の初期勾配を表すパラメータである。 本研究で用いた渦相関法計測のクオリティチェック, フラッ クス算出プロセス抢よび久測值補完済みの $N E E, R E$, GPP の推定方法の詳細については, Saitoh et al. (2010) を参照されたい。また， $S_{\mathrm{NEP}}, S_{\mathrm{GPP}}, S_{\mathrm{RE}}$ の推定精度を調 べるために，渦相関法による久測值補完済夕炭素収支量 推定の際に生じる誤差についての検討を行った (例えば, Baldocchi et al., 2003)。結果として，炭素収支量推定 の際に生じる誤差が $S_{\mathrm{NEP}}, S_{\mathrm{GPP}}, S_{\mathrm{RE}}$ の推定精度に与え る影響は Fig. 1 ～Fig. 3 および Table 1, Table 2 にお いて $\pm 0.5 \mathrm{~W} \mathrm{~m}^{-2}\left(\mathrm{CO}_{2}\right.$ 換算では約 $\left.\pm 1 \mu \mathrm{mol} \mathrm{m}^{-2} \mathrm{~s}^{-1}\right)$ 以内であった。

\subsection{3 貯熱量の推定}

光合成に伴うグルコース生成の化学式は次式で表すこ とができる。

$$
6 \mathrm{CO}_{2}+12 \mathrm{H}_{2} \mathrm{O} \stackrel{\text { light }}{\longrightarrow} \mathrm{C}_{6} \mathrm{H}_{12} \mathrm{O}_{6}+6 \mathrm{H}_{2} \mathrm{O}+6 \mathrm{O}_{2}
$$

その際, $1 \mathrm{~mol}$ のグルコースの生成に必要なエネルギー は $2.87 \times 10^{6} \mathrm{~J}$ である (Moderow et al., 2009)。結果 として，1 $\mu \mathrm{molCO}_{2}$ の固定に利用されるエネルギー

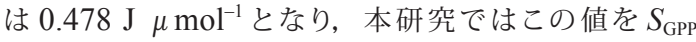
推定の際の熱換算係数 $(\mu)$ として採用した。なお， $\mu$ は，文献によって異なる值が採用されており，0.469

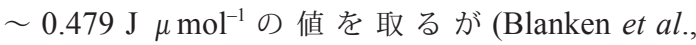
1997 ; Bernhofer et al., 2003 ; Oncley et al., 2007 ; Moderow et al., 2009), その誤差は $2.5 \%$ 以内である。 また, NEP および呼吸に伴う貯熱量に関しても同様の $\mu$ を利用可能であり (Blanken et al., 1997 ; Bernhofer et $a l ., 2003), S_{\mathrm{NEP}}, S_{\mathrm{RE}}, S_{\text {Rabove }}, S_{\mathrm{Rsoil}}$ の算出の際にも $S_{\mathrm{GPP}}$ と同様の $\mu$ を用いた。

本研究では, 2.2.2 項で得られた $N E E, G P P, R E$ の 30 分值と $\mu$ を用いて以下の式より, $S_{\mathrm{NEP}}, S_{\mathrm{GPP},} S_{\mathrm{RE}}$ を推 定した。

$$
\begin{aligned}
& S_{\mathrm{NEP}}=-\mu N E E \\
& S_{\mathrm{GPP}}=\mu G P P \\
& S_{\mathrm{RE}}=-\mu R E
\end{aligned}
$$

また，土壌呼吸量に単位換算係数および $\mu$ を乗じ ることで (4) 式の $S_{\text {Rsoil }}$ を得た。土壌呼吸量推定には, TKC サイトの観測值を基に得られた以下の式 (Lee and 
Koizumi, 2009)を用いた。

$$
R_{\text {soil }}=116.78 \times \exp \left(0.080 \times T_{\text {soil }}\right)\left(R^{2}=0.64\right)
$$

ここで, $R_{\text {soil }}$ は土壌呼吸量 $\left(\mathrm{mgCO}_{2} \mathrm{~m}^{-2} \mathrm{~h}^{-1}\right), T_{\text {soil }}$ は深 度 $5 \mathrm{~cm}$ の地温 ( $\left.{ }^{\circ} \mathrm{C}\right)$ である。また, $S_{\text {Rabove }}$ を(4) 式より, $S_{\mathrm{RE}}$ と $S_{\mathrm{Rsoil}}$ の残差として得た。

$S_{\mathrm{C}}$ との比較に用いた $S_{\mathrm{H}}, S_{\mathrm{LE}}, S_{\mathrm{V}}$ は次のように推定し た。 $S_{\mathrm{H}}$ および $S_{\mathrm{LE}}$ は渦相関法計測高度以下の気温およ び水蒸気密度の時間変化によって推定した (Oliphant et al. 2004)。その際, 気温および水蒸気密度は渦相関法 計測高度以下 8 高度の気温・湿度計測から得られた值を 用いた。 $S_{\mathrm{V}}$ は次式により推定した (例えば, Moore and Fisch, 1986)。

$$
S_{\mathrm{V}}=S_{\text {stem }}+S_{\mathrm{bl}}
$$

ここで, $S_{\mathrm{stem}}$ は幹による貯熱量 $\left(\mathrm{W} \mathrm{m}^{-2}\right)$ であり， $S_{\mathrm{bl}}$ は 枝葉による貯熱量である $\left(\mathrm{W} \mathrm{m}^{-2}\right)$ 。 $S_{\mathrm{stem}}$ は幹の形状を円 錐形と想定した熱拡散方程式を基に推定した (Kondo et al., 1991)。なお, 境界条件として幹の表面温度に代えて 6 高度の気温 $(18.4,14.7,10.6,6.5,3.6$, and $1.3 \mathrm{~m})$ を 利用した (例えば, Kondo et al., 1991)。 $S_{\mathrm{bl}}$ は気温変 化によく対応することから, $S_{\mathrm{bl}}$ は, 樹冠付近の $18.4 \mathrm{~m}$ 高 度の気温の時間変化にバイオマス量と比熱量を乗じること で推定した(例えば, Moore and Fisch, 1986)。

\section{3. 結 果}

\subsection{TKC サイトにおける貯熱量・放熱量の日変化}

Fig. 1 によれば, TKC サイトの降雪期間 (11月〜 4 月 ) および無降雪期間 (5 月〜 10 月 ) における $S_{\mathrm{NEP}}$ およ び $S_{\mathrm{GPP}}$ は, 正午前 (11 時〜 12 時) に最大值をとり, こ の時刻に貯熱量が最大となった。一方, $S_{\mathrm{RE}}$ は, 13 時 30 分〜 14 時に最小值をとり, この時刻の放熱量が最大 となった。結果として $S_{\mathrm{NEP}}, S_{\mathrm{GPP}}$ の最大值が現れる時刻, $S_{\mathrm{RE}}$ の最小值が現れる時刻に期間による相異はなかった。 $S_{\mathrm{GPP}}$ は常にゼロ以上の值をとり, その最大值は降雪期間 で $4.0 \mathrm{~W} \mathrm{~m}^{-2}$, 無降雪期間で $11.4 \mathrm{~W} \mathrm{~m}^{-2}$ であった。一方, $S_{\mathrm{RE}}$ は常に負の值をとり, その最小值は降雪期間で -1.3 $\mathrm{W} \mathrm{m}{ }^{-2}$, 無降雪期間で $-4.9 \mathrm{~W} \mathrm{~m}^{-2}$ であり, その最大值 は降雪期間で $-0.6 \mathrm{~W} \mathrm{~m}^{-2}$, 無降雪期間で $-2.9 \mathrm{~W} \mathrm{~m}^{-2}$

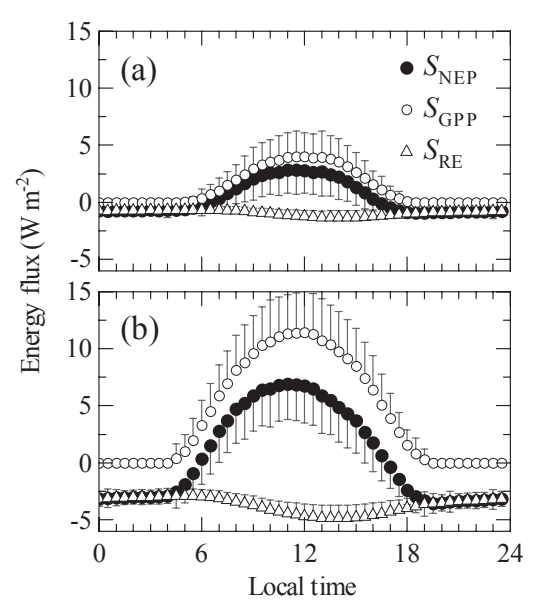

Fig. 1. Mean diurnal variations of $S_{\mathrm{NEP}}, S_{\mathrm{GPP}}$ and $S_{\mathrm{RE}}$ during (a) snowfall period (November-April) and (b) snow-free period (May-October) at the TKC site. Each value was taken from ensemble means of each period by using continuous data from November 2005 to October 2008. Vertical bar shows standard deviation.

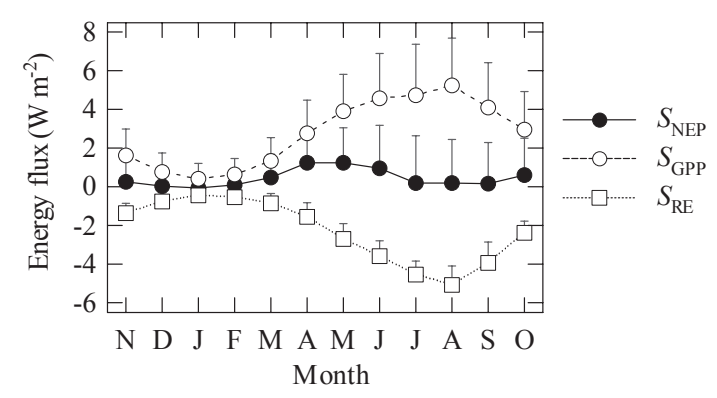

Fig. 2. The monthly mean values of $S_{\mathrm{NEP}}, S_{\mathrm{GPP}}$ and $S_{\mathrm{RE}}$ from November to October at the TKC site. Each value was taken from ensemble means of each month by using continuous data from November 2005 to October 2008.

であった。結果として, 無降雪期の $S_{\mathrm{NEP}}$ の振幅 $10.4 \mathrm{~W}$ $\mathrm{m}^{-2}, S_{\mathrm{GPP}}$ の振幅 $11.4 \mathrm{~W} \mathrm{~m}^{-2}, S_{\mathrm{RE}}$ の振幅 $2.0 \mathrm{~W} \mathrm{~m}^{-2}$ のいずれの值も降雪期の $S_{\mathrm{NEP}}$ の振幅 $3.8 \mathrm{~W} \mathrm{~m}^{-2}, S_{\mathrm{GPP}}$ の振幅 $4.0 \mathrm{~W} \mathrm{~m}^{-2}, S_{\mathrm{RE}}$ の振幅 $0.7 \mathrm{~W} \mathrm{~m}^{-2}$ と比較して大 きな值であった。一方で, $S_{\mathrm{LE}}$ の最大值は, 降雪期間で

Table 1. The half-annual mean values of $S_{\mathrm{NEP}}, S_{\mathrm{GPP}}, S_{\mathrm{RE}}, S_{\mathrm{Rsoil}}$, and $S_{\text {Rabove }}$ in snowfall and snow-free periods at the TKC site. Numbers in parentheses indicate standard deviation.

\begin{tabular}{lccccc}
\hline period & $S_{\mathrm{NEP}}\left(\mathrm{W} \mathrm{m}^{-2}\right)$ & $S_{\mathrm{GPP}}\left(\mathrm{W} \mathrm{m}^{-2}\right)$ & $S_{\mathrm{RE}}\left(\mathrm{W} \mathrm{m}^{-2}\right)$ & $S_{\text {Rsoil }}\left(\mathrm{W} \mathrm{m}^{-2}\right)$ & $S_{\text {Rabove }}\left(\mathrm{W} \mathrm{m}^{-2}\right)$ \\
\hline Snowfall & $0.4(0.5)$ & $1.3(0.9)$ & $-0.9(0.4)$ & $-0.4(0.1)$ & $-0.5(0.4)$ \\
Snow-free & $0.6(0.5)$ & $4.3(0.8)$ & $-3.7(1.0)$ & $-1.3(0.4)$ & $-2.4(0.7)$ \\
\hline
\end{tabular}



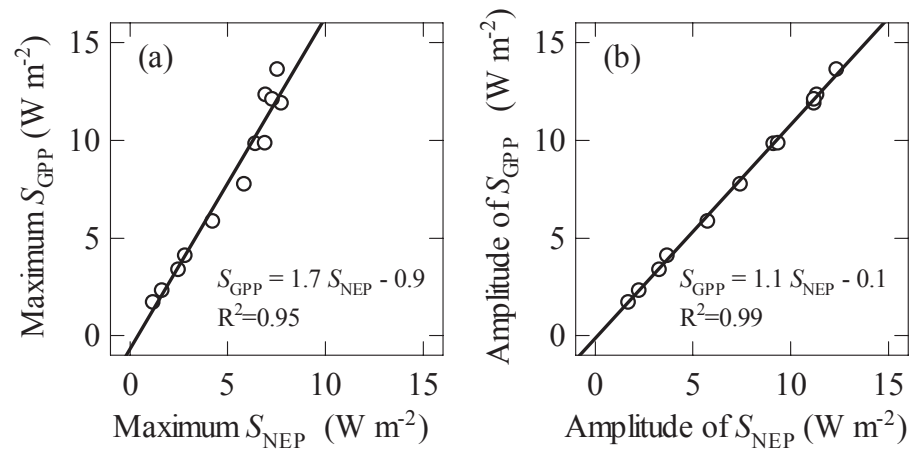

Fig. 3. (a) Relationship between the mean daily maximum value of $S_{\mathrm{NEP}}$ and that of $S_{\mathrm{GPP}}$ and (b) relationship between the mean daily amplitude of $S_{\mathrm{NEP}}$ and that of $S_{\mathrm{GPP}}$ at the TKC site. The maximum values and amplitude were taken from mean diurnal variations of $S_{\mathrm{NEP}}$ and $S_{\mathrm{GPP}}$ in each month during the study period.

Table 2. The maximum and minimum $S_{\mathrm{NEP}}$ taken from mean diurnal variations during the observation period in several forest ecosystems. The $S_{\mathrm{NEP}}$ was estimated by using $N E E$ values based on equation (8), except Bernhofer et al. (2003).

\begin{tabular}{|c|c|c|c|c|c|c|c|}
\hline \multirow{2}{*}{$\begin{array}{l}\text { Source } \\
\text { This study }\end{array}$} & \multirow{2}{*}{$\begin{array}{c}\begin{array}{c}\text { Forest } \\
\text { type }\end{array} \\
\text { ECF }\end{array}$} & \multirow{2}{*}{$\begin{array}{c}\text { Canopy } \\
\text { height (m) }\end{array}$} & \multirow{2}{*}{$\begin{array}{c}\begin{array}{c}\text { Leaf area } \\
\text { index }\end{array} \\
\left(\mathrm{m}^{2} \mathrm{~m}^{-2}\right)\end{array}$} & Age $(\mathrm{yr})$ & \multirow[t]{2}{*}{$\begin{array}{c}\begin{array}{c}\text { Observation } \\
\text { period }\end{array} \\
\end{array}$} & \multicolumn{2}{|c|}{$\begin{array}{l}\text { Max. and min. } \\
\text { values of } S_{\mathrm{NEP}} \\
\quad\left(\mathrm{W} \mathrm{m}^{-2}\right)\end{array}$} \\
\hline & & & & $40-50$ & & 3 & -1 \\
\hline This study & ECF & 20 & $5^{\mathrm{d})}$ & $40-50$ & snow-free $(3-y r)$ & 7 & -4 \\
\hline Anthoni et al. (1999) & ECF & 33 & 2 & -250 & late summer (10d) & 5 & -3 \\
\hline Baldocchi and Vogel $(1996)^{\mathrm{a}}$ & ECF & 14 & 2 & $75-90$ & Sep. (1d) & 4 & -1 \\
\hline Bernhofer et al. (2003) & $\mathrm{ECF}$ & 19 & 6 & 45 & Jul. (31d) & 6 & - \\
\hline Bernhofer et al. (2003) & ECF & 29 & 8 & 113 & Jul. (31d) & 5 & - \\
\hline Bernhofer et al. (2003) b) & ECF & 6.8 & 8 & 15 & Jul. (31d) & 7 & - \\
\hline Bernhofer et al. (2003) b) & ECF & 29 & 7 & 110 & Jul. (31d) & 3 & - \\
\hline Dolman et al. (2002) & ECF & 15 & 2 & - & Jun.-Jul. (10d) & 8 & -4 \\
\hline Jarvis et al. (1997) & ECF & $10-11$ & 5 & - & May-Sep. (114d) & 4 & -1 \\
\hline Hollinger et al. (1998) & ECF & $15-18$ & 1 & -125 & Jul. (14d) & 3 & -1 \\
\hline Aubinet et al. (2001) & MF & $27-35$ & - & $35-61$ & Sep. (1d) & 10 & -2 \\
\hline Baldocchi and Vogel $(1996)^{\mathrm{a}}$ & DBF & 24 & 5 & 50 & Aug. (1d) & 8 & -7 \\
\hline Goulden et al. (1996) & DBF & $20-24$ & - & $50-70$ & Aug.-Sep. (3d) & 9 & -2 \\
\hline Valentini et al. (1996) & DBF & 20 & - & 90 & Jun. (1d) & 12 & -3 \\
\hline Valentini et al. (1996) & DBF & 20 & - & 90 & Aug. (1d) & 8 & -2 \\
\hline Grace et al. (1996) & TRF & 30 & 4 & - & May-Jun. (44d) & 7 & -4 \\
\hline Malhi et al. (1998) & TRF & 30 & $5-6$ & - & Jan.-Mar. (89d) & 9 & -4 \\
\hline Malhi et al. (1998) & TRF & 30 & $5-6$ & - & Jul.-Aug. (46d) & 7 & -3 \\
\hline Malhi et al. (1998) & TRF & 30 & $5-6$ & - & Oct.-Nov. (32d) & 7 & -3 \\
\hline Vourlitis et al. (2001) & TRF & $28-30$ & 4 & - & Feb.-Apr. (6d) & 10 & -7 \\
\hline Vourlitis et al. (2001) & TRF & $28-30$ & 4 & - & Aug.-Sep. (29d) & 4 & -2 \\
\hline Vourlitis et al. (2001) & TRF & $28-30$ & 4 & - & Oct.-Nov. (37d) & 4 & -2 \\
\hline Yasuda et al. (2003) & TRF & $35-45$ & 6 & - & March (3d) & 11 & -2 \\
\hline
\end{tabular}
a) $S_{\mathrm{NEP}}$ was estimated by using $N E E$ values without storage $\mathrm{CO}_{2}$ flux.
b) $S_{\text {NEP }}$ values reported by Bernhofer et al. (2003).
c) ECF: Evergreen coniferous forest; MF: Mixed forest; DBF: Deciduous broad-leaf forest; TRF: Tropical rain forest
d) Plant area index $\left(\mathrm{m}^{2} \mathrm{~m}^{-2}\right)$ 
$2.2 \mathrm{~W} \mathrm{~m}^{-2}$, 無降雪期間で $7.5 \mathrm{~W} \mathrm{~m}^{-2}$ であり, $S_{\mathrm{H}}, S_{\mathrm{V}}$ の 最大值は降雪期間，無降雪期間で明膫な違いはなく 16.9 〜 $23.3 \mathrm{~W} \mathrm{~m}^{-2}$ であった。また, 降雪期間, 無降雪期間 における $S_{\mathrm{H}}+S_{\mathrm{LE}}+S_{\mathrm{V}}$ は日の出から日の入り頃まで正 の值をとり, $S_{\mathrm{H}}+S_{\mathrm{LE}}+S_{\mathrm{V}}$ の最大值は両期間ともに 40 $\mathrm{W} \mathrm{m}{ }^{-2}$ 程度であった。

\subsection{TKC サイトにおける貯熱量・放熱量の平均値}

Fig. 2 によれば, $S_{\mathrm{GPP}}, S_{\mathrm{RE}}$ は明膫な季節変化を示し, 夏季に最大の貯熱量, 放熱量となった。一方で, $S_{\mathrm{NEP}}$ は 4 月〜 6 月に高い正の值を示した。

Table 1 によれば, $S_{\mathrm{NEP}}, S_{\mathrm{GPP}}, S_{\mathrm{RE}}, S_{\mathrm{Rsoil}}, S_{\text {Rabove }}$ の すべての項で，降雪期間より無降雪期間においてその 絶対值は大きかった。最も大きな值は無降雪期における $S_{\mathrm{GPP}}$ であり $4.3 \mathrm{~W} \mathrm{~m}^{-2}$ に達した。また, $S_{\mathrm{NEP}}$ は降雪期間, 無降雪期間ともに正の值を示した。

\section{$3.3 \mathrm{TKC}$ サイトにおける $S_{\mathrm{NEP}}$ と $S_{\mathrm{GPP}}$ の関係}

$S_{\mathrm{NEP}}$ と $S_{\mathrm{GPP}}$ の関係は $S_{\mathrm{C}}$ と他の貯熱項を比較する際 の重要な情報となるため, Fig. 3 に両者の関係を示す。 $S_{\mathrm{GPP}}$ の各月の平均日最大值は $S_{\mathrm{NEP}}$ の各月の平均日最大 值より約 70\%大きな值を示した (Fig. 3a)。また， $S_{\mathrm{GPP}}$ の 各月の平均日振幅は $S_{\mathrm{NEP}}$ の各月の平均日振幅より約 $9 \%$ 大きな值を示した (Fig. 3b)。さらに，その散布図のバラ ツキは非常に小さく $\left(\mathrm{R}^{2}=0.95 \sim 0.99\right)$, 両者の関係は 季節によらずほぼ一定であった。

\section{4 様々な森林サイトにおける $S_{\mathrm{NEP}}$}

Table 2 に TKC サイトにおける $S_{\mathrm{NEP}}$ 打よび文献検索 の結果得られた $N E E$ 值から (8) 式を用いて推定した $S_{\mathrm{NEP}}$ の最大值・最小值をまとめた。なお,一部の $S_{\mathrm{NEP}}$ 值 (Table 2 参照) は樹冠上 $\mathrm{CO}_{2}$ フラックスの值から推定してお り, この場合, $S_{\mathrm{NEP}}$ の最大值は数 \% 30\%程度過小評 価される (例えば, Antoni et al., 1999; Yasuda et al., 2003)。TKC サイトの結果を除いて 22 件の $S_{\mathrm{NEP}}$ の最大 值および 18 件の $S_{\mathrm{NEP}}$ の最小值が得られた。なお,これ らの文献からは冬季の結果は得られず, Table 2 の值は すべて無降雪期間のものである。これらの報告から得られ た, $S_{\mathrm{NEP}}$ の最大值は $3 \sim 12 \mathrm{~W} \mathrm{~m}^{-2}$, 最小值は $-1 \sim-7$ $\mathrm{W} \mathrm{m}{ }^{-2}$ であり, $\mathrm{S}_{\mathrm{NEP}}$ の振幅は $4 \sim 17 \mathrm{~W} \mathrm{~m}^{-2}$ であった。 また, $S_{\mathrm{NEP}}$ の最大值, 最小值, 振幅の平均值は, $6.7 \mathrm{~W}$ $\mathrm{m}^{-2},-2.9 \mathrm{~W} \mathrm{~m}^{-2}, 9.6 \mathrm{~W} \mathrm{~m}^{-2}$ であり, TKCサイトの無 降雪期間に扔ける值に近かった。

\section{4. 考察}

\section{1 貯熱量・放熱量の日変化}

$\mathrm{TKC}$ サイトでは, 降雪期間においても $S_{\mathrm{NEP}}, S_{\mathrm{GPP}}$ が 明瞭な日変化を示した。その理由として, TKC サイトは 冷温帯に位置するものの降雪期間であっても常に雪に覆
われているわけではなく光合成活動が行われている点が 挙げられる(Satioh et al., 2010)。落葉があり冬季に光 合成活動がない落葉広葉樹林では，TKC サイトと異な り, 落葉期間中に $S_{\mathrm{GPP}}$ は常にゼロとなり, $S_{\mathrm{NEP}}$ の日変 化は小さいと思われる。TKC サイトにおける無降雪期間 については, 光合成活動が活発なため降雪期間と比較し て $S_{\mathrm{NEP}}, S_{\mathrm{GPP}}$ の日変化がより大きくなったと考えられる。 $S_{\mathrm{NEP}}, S_{\mathrm{GPP}}$ と比較すると $S_{\mathrm{RE}}$ の振幅は小さいがその日変 化は明瞭であった。また, 無降雪期間では, 降雪期間に 比べて放熱量が多かった。これは, 無降雪期間で，(1) 光合成活動が活発になり植物体の成長呼吸が増加した影 響 (Amthor, 2000), (2) 地温が高く微生物による分解が 促進された影響 ( 例えば Lee et al., 2008)，によるものと 考えられる。冷温帯から温帯に属する様々な森林におい て春季から秋季に光合成活動, 呼吸活動が活発になるこ とが知られており (例えば, Saigusa et al., 2008), 冷温 帯から温帯に属する森林では同様の貯熱, 放熱の傾向を 示すと思われる。

ところで, 観測に基づいて (2) 式右辺の各貯熱項を推 定し, それらの和から $S$ を推定する場合, $S_{\mathrm{C}}$ 以外の項の 取り扱いによって $S_{\mathrm{C}}$ の推定方法に違いが生じるため注意 を必要とする。例えば, $S_{\mathrm{V}}$ や $S_{\mathrm{H}}$ をその温度変化によって 推定した場合, 地上部呼吸に伴う放熱 (すなわち $S_{\text {Rabove }}$ ) はこれらの温度変動によってすでに考慮されていると考え ることができる。このため, $S_{\mathrm{C}}$ の推定の際には重複して 考慮しないように $S_{\text {Rabove }}$ を無視する必要がある (例えば Blanken et al., 1997)。同様に, $G$ を地温変化によって 推定した場合 (すなわち地中の貯熱量を考慮した場合), 地下部の呼吸に伴う放熱 (すなわち $S_{\text {Rsoil }}$ ) は, 地温変化

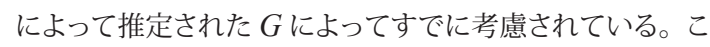
のため, $S_{\mathrm{C}}$ の推定の際には $S_{\mathrm{Rsoil}}$ を無視する必要がある (例えば, Moderow et al., 2009)。Gの推定手法として は, 熱流板とその埋設深度上部の地温変化によって $G$ を 推定する方法も一般的である。 $S_{\text {Rsoil }}$ を構成する微生物呼 吸と根呼吸に伴う放熱は多くの森林で深度が浅いほど大 きいことが知られており (Luo and Zhou, 2006), 熱流板 とその埋設深度上部の地温変化によって $G$ を推定した場 合も $S_{\text {Rsoil }}$ のほとんどは $G$ にってすでに考慮されている とみなすべきであろう。 $S_{\text {Rabove }}, S_{\text {Rsoil }}$ 両者を無視した場 合, 結果として $S_{\mathrm{C}}$ は $S_{\mathrm{GPP}}$ と等しいと考えることができる(例 えば, Moderow et al., 2009)。実際に, S 推定を行つ ている多くの研究 (例えば, Oliphant et al., 2004)では, $S_{\mathrm{V}}, S_{\mathrm{H}}$ はその温度変化によって推定し, $G$ は熱流板とそ の埋設深度上部の地温変化によって推定している。TKC サイトに打いても $S_{\mathrm{V}}, S_{\mathrm{H}}, G$ を温度変化により推定して

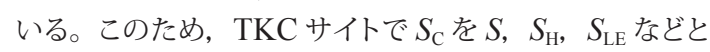


比較する場合は， $S_{\mathrm{C}}$ は $S_{\mathrm{GPP}}$ に等しいと考えるべきであり, 本稿 $4.1 \sim 4.3$ 節ではこの考えに基づき議論を展開した。

$\mathrm{TKC}$ サイトでは $S_{\mathrm{GPP}}$ の各月の平均日最大值抢よで振 幅は $S_{\mathrm{NEP}}$ の各月の平均日最大值および振幅より常に大き な值を示し，とくに各月の平均日最大值に関しては， $S_{\mathrm{GPP}}$ が $S_{\mathrm{NEP}}$ の $170 \%$ に達した (Fig. 3)。実際, (3) 式より $S_{\mathrm{GPP}}$ の平均日最大值は $S_{\mathrm{NEP}}$ の平均日最大值より観測サイ トによらず常に大きくなる。また, $S_{\mathrm{GPP}}$ の振幅と $S_{\mathrm{NEP}}$ の 振幅の差は, その両者の関係から日中の $S_{\mathrm{RE}}$ と夜間の $S_{\mathrm{RE}}$ の差に依存する。一般的に夜間の生態系呼吸量より 日中の生態系呼吸量が大きいことを考慮すると (例えば Amthor, 2000), 森林タイプによらず $S_{\mathrm{GPP}}$ の振幅は $S_{\mathrm{NEP}}$ の振幅より大きくなる。ただし, その関係は森林毎に異な ることが予想される。これら $S_{\mathrm{NEP}}$ と $S_{\mathrm{GPP}}$ の関係を考慮す ると, 様々な森林における無降雪期間における $S_{\mathrm{C}}$ の最大 值およびその振幅は本稿で提示した $S_{\mathrm{NEP}}$ の最大值 3 $12 \mathrm{~W} \mathrm{~m}^{-2}, S_{\mathrm{NEP}}$ の振幅 4 〜 $17 \mathrm{~W} \mathrm{~m}^{-2}$ よりも少なくとも 同值かまたは大きくなると考えることができる。

$\mathrm{TKC}$ サイトにおける $S_{\mathrm{C}}\left(\right.$ ここでは $S_{\mathrm{GPP}}$ ) は降雪期間, 無降雪期間ともに正午前に最大となった (Fig. 1)。一方, 同期間の $S_{\mathrm{H}}+S_{\mathrm{LE}}+S_{\mathrm{V}}$ は日の出から日の入り頃まで正 の值をとり, それ以外の時間は負の值をとる。このため, $S_{\mathrm{C}}$ を考慮することによって, $S$ の振幅は増加すると考えら れる。TKC サイトの降雪期間, 無降雪期間における $S_{\mathrm{H}}$ $+S_{\mathrm{LE}}+S_{\mathrm{V}}$ の最大值は両期間ともに $40 \mathrm{~W} \mathrm{~m}^{-2}$ 程度で あり, 本研究で得られた $S_{\mathrm{C}}$ を考慮することによって降雪 期間, 無降雪期間に扔ける $S$ の最大值は $43 \mathrm{~W} \mathrm{~m}^{-2}, 49$ $\mathrm{W} \mathrm{m}{ }^{-2}$ となる。このとき, $S$ のうち $S_{\mathrm{C}}$ が占める割合は降 雪期間では $10 \%$ 以下であるが，無降雪期間では $15 \%$ 以 上に達した。これら結果は, $S$ 推定の際に必ずしも $S_{\mathrm{C}}$ を 無視してよいとは言えないことを示唆する。 $S$ の推定の目 的に応じて $S_{\mathrm{C}}$ を無視することが可能かどうか十分検討す ることが必要であろう。

\section{2 貯熱量・放熱量の平均値}

$\mathrm{TKC}$ サイトにおける $S_{\mathrm{GPP}}, S_{\mathrm{RE}}$ は夏季に最大の貯熱量, 放熱量となるが， $S_{\mathrm{NEP}}$ は春から初夏に高い正の值を示し た (Fig. 2)。東南アジアの冷温帯から温帯に属する様々 な森林においては, 欧米の森林と比較して夏季の乾燥ス卜 レスの影響が小さいため, $G P P, R E$ が夏季に最大值と なる明瞭な季節変化を示すことが知られている (Saigusa et al., 2008)。このため, 東南アジアの泠温帯から温帯に 属する森林では $S_{\mathrm{GPP}}, S_{\mathrm{RE}}$ の季節変化はその絶対值に違 いはあるものの, 本研究で得られた結果と同様の貯熱量, 放熱量の季節変化を示すと思われる。一方で, NEP の 季節変化は森林タイプ毎に異なり, 春季から初夏に $N E P$ が最大值を取る特徴は常緑針葉樹林や混交林で見ること
ができる (Saigusa et al., 2008)。このため, 本研究サイ トのように春から初夏に $S_{\mathrm{NEP}}$ が最大となる森林は限定的 であると考えられる。

$S_{\mathrm{C}}$ に関連する貯留項の特徴として期間平均值がゼロに ならないという点が挙げられる (Table 1)。TKC サイトの 無降雪期間におけるインバランス補正済みの $H, L E$ の期 間平均値は $62.2 \sim 88.5 \mathrm{~W} \mathrm{~m}^{-2}$ であり, $S_{\mathrm{GPP}}$ の期間平 均值 $4.3 \mathrm{~W} \mathrm{~m}^{-2}$ は $H$ および $L E$ の $4.9 \sim 7.0 \%$ に達する。 また, 全球数值予報モデルに対する要求として, 放射量 に関連した観測精度は $1 \mathrm{~W} \mathrm{~m}^{-2}$ 程度が理想とされ, 現実 的には $10 \mathrm{~W} \mathrm{~m}^{-2}$ 程度の精度が求められている (World Meteorological Organization., 2010)。本研究で得られ た結果は, これらの值と比較しても決して小さい值ではな い。一方で, $R_{\mathrm{n}}, H, L E$ の観測值は 5-20\%程度の䛊差 を持つとされる(Foken, 2008)。これらを考慮すると, 熱 収支モデルに $S_{\mathrm{C}}$ を組み込むべきか否かは, 状況によって 異なると思われる。

\section{3 各貯留項との比較}

ここでは, $S_{\mathrm{C}}$ と (2) 式の $S_{\mathrm{C}}$ 以外の貯留項との比較を行 うため, 平均日最大值について考える。 $\mathrm{TKC}$ サイトにお ける $S_{\mathrm{C}}$ (ここでは $\left.S_{\mathrm{GPP}}\right)$ の平均日最大值は, 降雪期間で $4.0 \mathrm{~W} \mathrm{~m}^{-2}$, 無降雪期間で $11.4 \mathrm{~W} \mathrm{~m}^{-2}$ であった。また, 様々な森林における主に夏季の $S_{\mathrm{NEP}}$ の最大值は $3 \sim 12$ $\mathrm{W} \mathrm{m}{ }^{-2}$ であり, これらの森林における $S_{\mathrm{C}}$ の最大值は $S_{\mathrm{NEP}}$ の最大值と同值以上と考えられる。一方で, TKC サイト における $S_{\mathrm{LE}}$ の最大值は, 降雪期間で $2.2 \mathrm{~W} \mathrm{~m}^{-2}$, 無降 雪期間で $7.5 \mathrm{~W} \mathrm{~m}^{-2}$ であり, $S_{\mathrm{H}}, S_{\mathrm{V}}$ の最大值は降雪期 間, 無降雪期間で明瞭な違いはなく 16.9-23.3 W m ${ }^{-2}$ で あった。また, Ohkubo and Kosugi (2008) は様々な森 林における $S_{\mathrm{LE}}$ および $S_{\mathrm{H}}$ の日最大值を文献検索により得 た。その結果, (1) $S_{\mathrm{LE}}$ の日最大值は, 冬季で $4 \sim 5 \mathrm{~W}$ $\mathrm{m}^{-2}$ (平均 $4.3 \mathrm{~W} \mathrm{~m}^{-2}$ ), それ以外の季節では, $8 \sim 27$ $\mathrm{W} \mathrm{m}^{-2}$ (平均 $10.7 \mathrm{~W} \mathrm{~m}^{-2}$ ) であり, (2) $S_{\mathrm{H}}$ の日最大值は 冬季で $5 \sim 15 \mathrm{~W} \mathrm{~m}^{-2}$ (平均 $10.7 \mathrm{~W} \mathrm{~m}^{-2}$ ), それ以外の 季節では, $13 \sim 41 \mathrm{~W} \mathrm{~m}^{-2}$ ( 平均 $22.2 \mathrm{~W} \mathrm{~m}^{-2}$ ) であるこ とを示した。これらの結果は, $S_{\mathrm{C}}$ の最大值は $S_{\mathrm{H}}, S_{\mathrm{V}}$ と 比較すると小さいが, $S_{\mathrm{LE}}$ と同程度かそれ以上の值となり えることを示している。

渦相関法計測を基にした熱収支の研究には，有効エネ ルギー $\left(R_{\mathrm{n}}-G-S\right)$ と乱流フラックス ( 渦相関法によって計 測された $H$ と $L E$ の和 ) は理論的には等しくなるが, 実 際の観測結果では両者が等しくならないという熱収支のイ ンバランス問題があり, この問題を常に考慮する必要があ る(Foken, 2008)。本研究の結果は, 熱収支のインバラ ンス問題について日中と夜間に分けて短い時間スケール で解析する場合， $S_{\mathrm{C}}$ が無視できるほど小さいとは限らな 
いことを示す。少なくとも $S$ 算出に与える $S_{\mathrm{C}}$ の影響が無 視できるほど小さいかを十分に検討したうえで $S_{\mathrm{C}}$ を無視 する必要がある。

\section{5. まとめ}

本研究では, これまであまり調査されてこなかった森林 における光合成・呼吸活動に伴う貯熱量について検討し た。常緑針葉樹林を対象とした渦相関法による $\mathrm{CO}_{2}$ フラッ クス計測に基づいた事例研究から，(1) 無降雪期間にお ける日中の $S_{\mathrm{C}}$ は $S$ の $15 \%$ 以上に達することがある。(2) $S_{\mathrm{C}}$ の 5 月から 10 月の平均值は $4.3 \mathrm{~W} \mathrm{~m}^{-2}$ であり, この 值は $H$ および $L E$ の $4.9 \sim 7.0 \%$ に達する, ことが分かっ た。また，様々な森林の無降雪期間における $S_{\mathrm{C}}$ の日最 大值および日変化の振幅はそれぞれ $3 \sim 12 \mathrm{~W} \mathrm{~m}^{-2}$ およ び 4〜 $17 \mathrm{~W} \mathrm{~m}^{-2}$ より大きな值となり, $S_{\mathrm{LE}}$ の日最大值お よび振幅と同程度となりえることが示された。これらの結 果は, $S_{\mathrm{C}}$ は必ずしも無視できるほど小さいとは限らないこ とを示唆する。森林の貯熱量やその周辺に関連した研究 では, 対象とする研究の状況にあわせて, $S_{\mathrm{C}}$ を無視する ことが可能か十分に検討することが必要であろう。

\section{謝辞}

岐阜大学流域圏科学研究センター・高山試験地の車戸 憲二氏および宮本保則氏には野外観測における研究の実 際において様々な面で便宜をはかっていただいた。また, 本論文の査読者の方々には適切な助言をいただいた。こ こに記して深甚の謝意を表します。なお, 本研究は日本 学術振興会 (JSPS) の岐阜大学 21 世紀 COE プログラム 「衛星生態学創生拠点」および日中韓フォーサイト事業 (JSPS・NRF・NSFC) の助成を受けて行われたもので ある。関係者各位に感謝いたします。

\section{References}

Amthor, J. S., 2000: The McCree-de Wit-Penning de Vries-Thornley respiration paradigms: 30 years later. Ann. Bot., 86, 1-20.

Anthoni, P. M., Law, B. E., and Unsworth, M. H., 1999: Carbon and water vapor exchange of an open-canopied ponderosa pine ecosystem. Agric. For. Meteorol., 95, 151-168.

Aubinet, M., Chermanne, B., Vandenhaute, M., Longdoz, B., Yernaux, M., and Laitat, E., 2001: Long term carbon dioxide exchange above a mixed forest in the Belgian Ardennes. Agric. For. Meteorol., 108, 293-315.

Baldocchi, D. D., 2003: Assessing the eddy covariance technique for evaluating carbon dioxide exchange rates of ecosystems: past, present and future. Global Change Biol., 9, 479492.

Baldocchi, D. D., and Vogel, C. A., 1996: Energy and $\mathrm{CO}_{2}$ flux densities above and below a temperate borad-leaved forest and a boreal pine forest. Tree Physiol., 16, 5-16.

Bernhofer, C., Aubinet, M., Clement, R., Grelle, A., Grunwald, T., Ibrom, A., Jarvis, P., Rebmann, C., Schulze, E. -D., and Tenhunen, J. D., 2003: Spruce forests (Norway and Sitka spruce, including douglas fir): carbon and water fluxes, balances, ecological and ecophysiological determinants. In Fluxes of Carbon, Water and Energy of European Forests, Ecological Studies, Vol. 163. (ed. By Valentini, R.). Springer, Heidelberg, pp. 99-123.

Blanken, P. D., Black, T. A., Yang, P. C., Neumann, H. H., Nesic, Z., Staebler, R., den Hartog, G., Novak, M. D., and Lee, X., 1997: Energy balance and canopy conductance of a boreal aspen forest: partitioning overstory and understory components. J. Geophys. Res., 102, 28915-28927.

Bonan, G. B., Davis, K. J., Baldocchi, D., Fitzjarrald, D., and Neumann, H., 1997: Comparison of NCAR LSM1 land surface model with BOREAS aspen and jack pine tower fluxes. J. Geophys. Res., 102, 29065-29075.

Dolman, A. J., Moors, E. J., and Elbers, J. A., 2002: The carbon uptake of a mid latitude pine forest growing on sandy soil. Agric. For. Meteorol., 111, 157-170.

Foken, T., 2008: The energy balance closure problem: an overview. Ecol. Appl., 18, 1351-1367.

Goulden, M. L., Munger, J. W., Fan, S. -M., Daube, B. C., and Wofsy, S. C., 1996: Measurements of carbon sequestration by long-term eddy covariance: Methods and a critical evaluation of accuracy. Global Change Biol., 2, 169-182.

Grace, J., Malhi, Y., Lloyd, J., McIntyre, J., Miranda, A. C., Meir, P., and Miranda, H. S., 1996: The use of eddy covariance at infer the net carbon dioxide uptake of Brazilian rain forest. Global Change Biol., 2, 209-218.

Hollinger, D. Y., Kelliher, F. M., Schulze, E. -D., Bauer, G., Arneth, A., Byers, J. N., Hunt, J. E., 
McSeveny, T. M., Kobak, K. I., and Milukova, I., 1998: Forest atmosphere carbon dioxide exchange in eastern Siberia. Agric. For. Meteorol., 90, 291306.

Jaeger, L., and Kessler, A., 1996: The HartX Period May 1992, Seen against the background of twenty years of energy balance climatorology at the Hartheim pine plantation. Theor. Appl. Climatol., 53, 9-21.

Jarvis, P. G., Massheder, J. M., Hale, S. E., Moncrieff, J. B., Rayment, M., and Scott, S. L., 1997: Seasonal variation of carbon dioxide, water vapor, and energy exchanges of a boreal black spruce forest. J. Geophys. Res., 102, 28953-28966.

Kondo, J., Nakazono, M., Yamazaki, T., and Kuwagata, T., 1991: Heat storage in forest trees. TENKI, 38, 123-127.

Lee, M. -S., Lee, J. -S., and Koizumi, H., 2008: Temporal variation in $\mathrm{CO}_{2}$ efflux from soil and snow surfaces in a Japanese cedar (Cryptomeria japonica) plantation, central Japan. Ecol. Res., 23, 777-785.

Lee, N. -Y., and Koizumi, H., 2009: Estimation of the number of sampling points required for the determination of soil $\mathrm{CO}_{2}$ efflux in two types of plantation in a temperate region. J. Ecol. Field Biol., 32, 67-73.

Lloyd, J., and Taylor, J. A., 1994: On the temperature dependence of soil respiration. Funct. Ecol., 8, 315 -323 .

Luo, Y. and Zhou, X., 2006: Soil respiration and the environment. Academic Press, San Diego, pp. 310.

Malhi, Y., Nobre, A. D., Grace, J., Kruijt, B., Pereira, M. G. P., Culf, A., and Scott, S., 1998: Carbon dioxide transfer over a Central Amazonian rain forest. J. Geophys. Res., 103, 31593-31612.

McCaughey, J. H., 1985: Energy balance storage terms in a mature mixed forest at Petawawa, Ontario - a case study. Boundary-Layer Meteorol., 31, 89-101.

McCaughey, J. H., and Saxton, W. L., 1988: Energy balance storage terms in a mixed forest. Agric. For. Meteorol., 44, 1-18.

Moore, C. J., and Fisch, G., 1986: Estimating heat storage in stems. Agric. For. Meteorol., 38, 147169.
Moderow, U., Aubinet, M., Feigenwinter, C., Kolle, O., Lindroth, A., Mölder, M., Montaganai, L., Rebman, C., and Bernhofer, C., 2009: Available energy and energy balance closure at four coniferous forest sites across Europe. Theor. Appl. Climatol., 98, 397-412.

Ohkubo, S., and Kosugi, Y., 2008: Amplitude and seasonality of storage fluxes for $\mathrm{CO}_{2}$, heat and water vapour in a temperate Japanese cypress forest. Tellus B, 60, 11-20.

Oliphant, A. J., Grimmond, C. S. B., Zutter, H. N., Schmid, H. P., Su, H. -B., Scott, S. L., Offerle, B., Randolph, J. C., and Ehman, J., 2004: Heat storage and energy balance fluxes for a temperate deciduous forest. Agric. For. Meteorol., 126, 185 201.

Oncley, P., Foken, T., Vogt, R., Kohsiek, W., DeBruin, H., Bernhofer, C., Christen, A., van Gorsel, E., Grantz, D., Feigenwinter, C., Lehner, I., Liebethal, C., Liu, H., Mauder, M., Pitacco, A., Ribeiro, L., and Weidinger, T., 2007: The energy balance experiment EBEX-2000. Part I: overview and energy balance. Boundary-Layer Meteorol., 123, $1-28$.

Saigusa, N., Yamamoto, S., Hirata, R., Ohtani, Y., Ide, R., Asanuma, J., Gamo, M., Hirano, T., Kondo, H., Kosugi, Y., Li, S. -G., Nakai, Y., Takagi, K., Tani, M., and Wang, H., 2008: Temporal and spatial variations in the seasonal patterns of $\mathrm{CO}_{2}$ flux in boreal, temperate, and tropical forests in East Asia. Agric. For. Meteorol., 148, 700-713.

Saitoh, T. M., Tamagawa, I., Muraoka, H., Lee, N. -Y. M., Yashiro, Y., and Koizumi, H., 2010: Carbon dioxide exchange in a cool-temperate evergreen coniferous forest over complex topography in Japan during two years with contrasting climates. J. Plant Res., 123, 473-483.

Sellers, P. J., Randall, D. A., Collatz, G. J., Berry, A. J., Field, C. B., Dazlich, D. A., Zhang, C., Collelo, G. D., and Bounoua, L., 1996: A revised land surface parameterization (SiB2) for atmospheric GCMs, Part I: Model Formulation. J. Climate., 9, 676-705.

Valentini, R., De Angelis, P., Matteucci, G., Monaco, R., Dore, S., and Mugnozza, G. E. S., 
1996: Seasonal net carbon dioxide exchange of a beech forest with the atmosphere. Global Change Biol., 2, 199-207.

Vogt, R., Bernhofer, C., Gay, L. W., Jaeger, L., and Parlow, E., 1996: The available energy over a Scots pine plantation: What's up for partitioning? Theor. Appl. Climatol., 53, 23-31.

Vourlitis, G. L., Filho, N. P., Hayashi, M. M. S., Nogueira, J. D. S., Caseiro, F. T., and Campero Jr, J. H., 2001: Seasonal variations in the net ecosystem $\mathrm{CO}_{2}$ exchange of a mature Amazonian transitional tropical forest (cerradão). Funct. Ecol., 15, 388-395.

Wilson, K. B., and Baldocchi, D. D., 2000: Seasonal and interannual variability of energy fluxes over a broadleaved temperate deciduous forest in North America. Agric. For. Meteorol., 100, 1-8.

World Meteorological Organization., 2010: Database of observational requirements. http://www.wmo. int/pages/prog/sat/Databases.html $<$ referred on 20/07/2010>.

Yasuda, Y., Ohtani, Y., Watanabe, T., Okano, M., Yokota, T., Liang, N., Tang, Y., Nik, A. R., Tani, M., and Okuda, T., 2003: Measurement of $\mathrm{CO}_{2}$ flux above a tropical rain forest at Pasoh in Peninsular Malaysia. Agric. For. Meteorol., 114, 235-244. 